\title{
Basel III and Abolition of Universal Banking Model - Implication for Nigerian Banks
}

\author{
${ }^{1}$ Dr. Agbaeze E. K and I. O. Onwuka ${ }^{2}$ \\ ${ }^{I}$ Department of Management, University of Nigeria, Enugu Campus, Nigeria \\ ${ }^{2}$ Department of Banking \& Finance, University of Nigeria, Enugu Campus, Nigeria
}

\begin{abstract}
In an apparent response to the global economic crisis which pulled down many global banks and exposed multiple weaknesses in regulation and banking structures, the Basel Committee on Banking Supervision agreed to new rules on the minimum level (capital ratio) and composite structure of Banks capital on the 12th of September, 2010. Broadly speaking, the new rules which are widely referred to as Basel III still stipulate a minimum Total Capital Ratio of $8 \%$. However, in addition to increasing the portion of the $8 \%$ requirement that is Core Tier 1 Capital (from 2\% to 4.5\%), it requires Banks to reserve more common equity under what it calls Capital Conservation Buffer (2.5\%). Thus, with this new buffer, Banks' Total Capital Ratios would rise to a minimum 10.50\%. However, these new capital requirements will be progressively implemented over an 8-year span, with full implementation taking effect by January 1, 2019 (BIS, 2010). The Central Bank of Nigeria in its response to the global developments gave hint to abolishing the operation of the 10-year old universal banking concept through a Circular No. BSD/DIR/GEN/UBM/03/025 dated September 7, 2010 Some of the reasons proffered by the regulatory body for the abolition include the enhancement of the quality of banks, financial system stability and evolution of a healthy financial sector, ensuring the protection of depositor funds by ring fencing "banking" from non-banking business; redefining the licensing model of banks and minimum requirements to guide bank operations going forward; effective regulation of the business of banks without hindering their growth aspirations; and facilitating more effective regulator intervention in public interest entities. In this paper, we reviewed the new rules on the minimum level (capital ratio) and composite structure of Banks capital and what it portends for Nigerian banks. We also reviewed how the abolition of the universal banking model would impact on banks in Nigeria. The study found that the new rules on the minimum level and structure of banks capital will not negatively affect Nigerian banks as most of the banks already have provisions above the new BIS requirements. We also highlighted the challenges Nigerian banks would face in the light of the new licensing model and capital requirements. We therefore, recommend that the Central Bank of Nigeria should be alive to its regulatory and monetary stability responsibilities to ensure the exercise do not amount to another rigmarole and futility.
\end{abstract}

Keywords: Universal Banking Model, Capital Structure, Bank for International Settlement

\section{Introduction:}

In the aftermath of the economic recession which pulled down many global banks and exposed multiple weaknesses in regulation and banking structures, the Basel Committee on Banking Supervision agreed to new rules on the minimum level (capital ratio) and composite structure of Banks capital on the 12th of September, 2010. Broadly speaking, the new rules which are widely referred to as Basel III (and are mainly Basel II plus new regulations based on lessons from the market crisis), still stipulate a minimum Total Capital Ratio of $8 \%$. However, in addition to increasing the portion of the $8 \%$ requirement that is Core Tier 1 Capital (from $2 \%$ to $4.5 \%$ ), it requires Banks to reserve more common equity under what it calls Capital Conservation Buffer (2.5\%), which in many respects is a modification of the IMF proposed 'Bank Tax'. Thus, with this new buffer, Banks' Total Capital Ratios would rise to a minimum 10.50\%. However, these new capital requirements will be progressively implemented over an 8 -year span, with full implementation taking effect by January 1 , 2019 (BIS, 2010). Furthermore, following the final assent to the Basel Committee's proposals at the Seoul G-20 Leaders Summit in November 2010, member countries of the Bank for International Settlement (BIS) are currently domesticating the proposal and making further amendment in line with the peculiarities of their country's financial system.

In apparent response to the developments in global financial community especially the new Basel III, the Central Bank of Nigeria in a Circular No. BSD/DIR/GEN/UBM/03/025 dated September 7, 2010 gave hint to abolishing the operation of the 10-year old universal banking concept. Some of the reasons proffered by the regulatory body for the abolition include the enhancement of the quality of banks, financial system stability and evolution of a healthy financial sector, ensuring the protection of depositor funds by ring fencing "banking" from non-banking business; redefining the licensing model of banks and minimum requirements to guide bank operations going forward; effective regulation of the business of banks without hindering their growth 
aspirations; and facilitating more effective regulator intervention in public interest entities. In the new licensing model, banking will be calibrated in a capital scale and fitted into a four-tier operating structure of international, national, regional and specialized institution. As part of the new structure, the Central bank also introduced a holding company model that permits a non-operating holding company to own bank and non-banks subsidiaries. The eventual ending of universal banking regime and the implementation of the new licensing model have far reaching implications for the banking industry. The most critical aspect of consideration according to Uzor (2010) is the fact that universal banking was a market induced evolution rather than a regulatory invention. It was the culmination of a quest to end competitive disadvantages for some class of banks and create level playing field for all. The new licensing model will tamper with the concept of level playing field in market place competition and return the industry to institutional distinctions.

The aim of this paper is to review the Basel III framework (the BIS new rules on capital) and its likely impact on Nigerian banks. The paper will also review the abolition of universal banking model and the new Banking structure in Nigeria, highlighting potential challenges and implications for banks in the country. To this end, the paper will be structured into six sections. Following this introduction, section 2 will review the Basel III capital framework. Section 3 will focus on the abolition of the universal banking model in Nigeria while section 4 will deal with the evolution of universal banking model in Nigeria. Section 5 will highlight the implications of abolishing the universal banking concept and the new banking model for banks in Nigeria while section 6 will conclude the paper.

\section{The New Basel III Framework}

The Basel Committee is a 35-year old sub-set of the Bank for International Settlements (BIS), which has as its members, the Central Bank Governors and Heads of Supervision of 27 countries - the BIS has 56 member countries. It is not a formal supranational supervisory authority; thus, its conclusions lack legal force. Nonetheless, it formulates broad supervisory standards and guidelines, and recommends statements of best practice in the expectation that individual authorities will take steps to implement these through detailed arrangements - statutory or otherwise - which are best suited to their own national systems. The Committee comprises 12 European, 8 Asian, 3 South American, 2 American and just one African Country, South Africa. The Basel rules have become widely accepted as minimum standards in Banking regulation for capital, Banking supervision and risk management, not just in the 56 member countries of BIS, but globally.

However, while the minimum total capital ratio stipulated by the Basel Committee is $8 \%$, most African Countries have higher minimum capital ratio requirements as shown in the table in Table One. Nigeria adopts a $10 \%$ floor. As Nigeria still lags in strict implementation of Basel II requirements, the implementation of Basel III would be even farther away. In an attempt to strengthen Banks' buffer levels in the aftermath of the economic recession, the Basel Committee on Banking Supervision agreed to new rules on the minimum level (capital ratio) and composite structure of what Banks call capital. Broadly speaking, the new rules which are widely referred to as Basel III and are majorly Basel II plus lessons from the market crisis, still stipulate a minimum Total Capital Ratio of $8 \%$. However, in addition to increasing the portion of the $8 \%$ that is Core Tier 1 Capital (to $4.5 \%$ from 2\%), it requires Banks to reserve more common equity under what it calls Capital Conservation Buffer (2.5\%), which to a large extent is a modification of the IMF proposed 'Bank Tax'. Thus, with this new buffer, Banks' Total Capital Ratios would rise to a minimum $10.50 \%$. However, these new capital requirements will be progressively implemented over an 8-year span, with full implementation taking effect by January 1, 2019 (BIS, 2010.

Table 1: Selected African Countries and Regulatory Requirement

\begin{tabular}{|l|l|}
\hline Country & Regulatory Requirement \\
\hline Botswana & $15 \%$ \\
\hline Uganda & $12 \%$ \\
\hline Tanzania & $12 \%$ \\
\hline Kenya & $12 \%$ \\
\hline Zimbabwe & $10 \%$ \\
\hline Zambia & $10 \%$ \\
\hline Nigeria & $10 \%$ \\
\hline Namibia & $10 \%$ \\
\hline Malawi & $10 \%$ \\
\hline Angola & $10 \%$ \\
\hline Ghana & $10 \%$ \\
\hline Mauritius & $10 \%$ \\
\hline DR Congo & $10 \%$ \\
\hline South Africa & $9.5 \%$ \\
\hline Swaziland & $8 \%$ \\
\hline Mozambique & $8 \%$ \\
\hline Liberia & $8 \%$ \\
\hline
\end{tabular}




\begin{tabular}{|l|l|}
\hline Lesotho & $8 \%$ \\
\hline Gambia & $8 \%$ \\
\hline Cameroon & $8 \%$ \\
\hline
\end{tabular}

Source: Standard Bank, 2010

As can be seen from Table 1 above, most African countries have adopted the Basel II capital framework in their different jurisdictions and some have even higher capital requirements beyond the Basel II framework but as noted elsewhere (see Vetiva 2009) Basel III is more expansive than above capital requirements. A clarification of Basel III framework is pertinent at this point.

\begin{tabular}{|c|l|l|l|}
\hline S/N & Total Regulatory Ratio & Basel II & Basel III \\
\hline 1 & Tier 1 Capital Ratio & $4.00 \%$ & $6.00 \%$ \\
& Core Tier 1 Capital Ratio (Common equity after deductions) & $2.00 \%$ & $4.50 \%$ \\
\hline
\end{tabular}

Tier 1 capital primarily comprises of common equity and retained earnings and sometimes, preferred stock. The use of deferred taxes and mortgage-servicing rights in Tier 1 capital computations will be curbed by 01 January, 2018 based on Basel III framework.

\begin{tabular}{|l|l|l|l|}
\hline S/N & Total Regulatory Ratio & Basel II & Basel III \\
\hline 2 & Tier 2 Capital Ratio & $4.00 \%$ & $2.00 \%$ \\
\hline & Sub-Total (1 + 2) & $\mathbf{8 . 0 0 \%}$ & $\mathbf{8 . 0 0 \%}$ (More Tier 1, less Tier 2 \\
\hline
\end{tabular}

Tier 2 capital primarily includes hidden reserves, revaluation reserves, qualified general provisions, hybrid debt instruments and subordinated term debt.

\begin{tabular}{|l|l|l|l|}
\hline S/N & Total Regulatory Ratio & Basel II & Basel III \\
\hline 3 & Capital Conservation Buffer & - & $2.50 \%$ \\
\hline & Sub-Total $(\mathbf{1 + 2 + 3 )}$ & $\mathbf{8 . 0 0 \%}$ & $\mathbf{1 0 . 5 0 \%}$ (More Tier 1 - common equity \\
\hline
\end{tabular}

Capital Conservation Buffer may be viewed as a modification of the IMF proposed 'Bank Tax', as it is effectively aimed at helping banks withstand future periods of stress. Furthermore, the closer the bank's capital ratios approach the minimum requirements, the higher the constraints on their earning distributions. Considering that this buffer will primarily be made of common equity (after the application of deductions like deferred taxes), it increases the common equity requirements in a bank's capital ratio to $7 \%$ (including $4.5 \%$ Core Tier 1 Capital).

\begin{tabular}{|c|c|l|l|}
\hline S/N & Total Regulatory Ratio & Basel II & Basel III \\
\hline 4 & Countercyclical Capital Buffer & - & $0 \%-2.5 \%$ \\
\hline
\end{tabular}

This would not be straight addition to the percentage points of the capital ratio, but a normal addition, as it will be computed as $0 \%-2.5 \%$ of bank's common equity or fully loss absorbing capital. However, this is not a blanket requirement, as its implementations will depend on domestic conditions in different countries. The phasing will be as follows:
$\checkmark \quad$ Before 2006
$0 \%$
$\checkmark \quad 01$ Jan $2006 \quad-\quad 0.65 \%$
$\checkmark \quad 01$ Jan $2017 \quad-\quad 1.25 \%$
$\checkmark \quad 01$ Jan $2018 \quad-\quad 1.87 \%$
$\checkmark \quad 01$ Jan $2019 \quad-\quad 2.5 \%$

\begin{tabular}{|l|l|l|l|}
\hline S/N & Total Regulatory Ratio & Basel II & Basel III \\
\hline 5 & Capital for Systemically Important Banks only & - & $0 \%-2.5 \%$ \\
\hline & Total Regulatory Capital Ratio $=\mathbf{1 + 2 + 3 + 4 + 5}$ & & \\
\hline
\end{tabular}

Source: Bank of International Settlement, 2010

This is a new introduction under Basel III, premised on the understanding that systemically important banks should have loss absorbing capacities higher than other banks. However, a framework to address this is still 
being worked out, but approaches like capital surcharges, contingent capital and bail-in-debt are under consideration.

Other key introduction in Basel III includes:

$\checkmark$ Liquidity Coverage Ratio (LCR) and Net Stable Funding Ratio (NSFR): The LCR marks a first attempt by the Basel Committee to set a global standard for liquidity needs, with a view to ensuring that banks hold more liquid assets to withstand stressed funding scenarios. It measures the stock of liquid assets (cash, Central Bank reserves, marketable sovereign securities, etc) available to cover net cash outflows. On the other hand, the NSFR seeks to match the available amount of stable funding with the required amount of stable funding. A minimum standard for the LCR will be introduced by 01 January 2015, while that of the NSFR will be set by 01 January 2018.

$\checkmark \quad$ Leverage Ratio: Phase-in-arrangements for the Leverage Ratio were announced on 26 July 2010. The supervisory monitoring period commenced on 01 January 2011; the parallel run period will commence on 01 January 2013 and run until 01 January 2017; though disclosure of the Leverage Ratio and its components will start on 01 January 2015. During the parallel run period, a minimum Tier 1 Leverage Ratio of $3 \%$ will be tested. For clarity, the Leverage Ratio here is computed as Total Assets/Tier 1 Equity; thus, a 3\% ratio would imply that bank's Total Assets cannot exceed 33x their Tier 1 Equity. The introduction of this ratio is to checkmate the shortcomings of the Capital Adequacy Ratio in curtailing the excessive use of leverage by banks in growing their assets (Vetiva, 2010).

Based on the foregoing and the Basel III timeline, it means that banks capital composition will be represented as shown in Table 2 below:

Table 2.1 - Capital Composition and Timeline

\begin{tabular}{|l|l|l|l|l|l|l|l|l|}
\hline Capital Composition & $\mathbf{2 0 1 2}$ & $\mathbf{2 0 1 3}$ & $\mathbf{2 0 1 4}$ & $\mathbf{2 0 1 5}$ & $\mathbf{2 0 1 6}$ & $\mathbf{2 0 1 7}$ & $\mathbf{2 0 1 8}$ & $\mathbf{2 0 1 9}$ \\
\hline Tier 1 & 2.00 & 3.50 & 4.00 & 4.00 & 4.50 & 4.50 & 4.50 & 4.50 \\
\hline Other Tier 1 & 2.00 & 1.00 & 1.50 & 1.50 & 1.50 & 1.50 & 1.50 & 1.50 \\
\hline Tier 2 & 4.00 & 2.50 & 2.50 & 2.00 & 2.00 & 2.00 & 2.00 & 2.00 \\
\hline Capital Conservation Buffer & - & - & - & - & 0.625 & 1.25 & 1.88 & 2.50 \\
\hline Total & $\mathbf{8 . 0 0}$ & $\mathbf{8 . 0 0}$ & $\mathbf{8 . 0 0}$ & $\mathbf{8 . 0 0}$ & $\mathbf{8 . 6 2 5}$ & $\mathbf{9 . 2 5}$ & $\mathbf{9 . 8 8}$ & $\mathbf{1 0 . 5 0}$ \\
\hline
\end{tabular}

Where,

Core Tier 1 Capital

Other Tier 1 Capital

$=\quad$ Common Equity and Retained Earnings

Tier 2 Capital

$=\quad$ Non-Redeemable Non-Cumulative Preferred Stock

= Hidden Reserves, Qualified General Provisions, Hybrid

Debt Instruments and Subordinated Term Debt

Capital Conservation Buffer $\quad=\quad$ Common Equity and Retained Earnings

Essentially, Basel III is all about attempt to increase banks' Tier 1 capital buffers to withstand periods of economic or liquidity stress. However, it is important to note that Basel III only addresses a few of the factors leading up to the recession (low common equity levels) and does not deal with other issues around accounting practices, supervisory shortcomings and poor ethical practices. These other subjects lie on the Central Banks, Legislators within each country's jurisdictions, and more importantly, Bankers themselves. Furthermore, Basel III is not a material business changer for the global Banking industry and the 8-year phasing of its changes gives such a long period for new risks to have been built up and advancements made in Banking, such that by 01 January 2019, the new capital requirements may have become somewhat irrelevant in the scope of things. However, while most systemically important BIS-member Banks currently have Tier 1 Capital Ratios well in excess of the $6 \%$ being proposed by 2019 , they will have to ensure that by then, $4.5 \%$ of this is Core Tier 1 Capital (common equity and retained earnings), up from the current $2 \%$ under Basel II. In addition, considering that the proposals of the Basel Committee on Supervision would be broadly accepted in member countries but with modifications, there may be opportunities for regulatory arbitrage in the medium term, which may impact market dynamics.

Broadly speaking, more common equity capital raisings are expected in the markets from Banks in the near term; however, the low-edge banks (based on Tier 1 capital) will be the quickest to do this in the years before 2013, by then they would be required to have a minimum of 3.5\% Core Tier 1 Capital in their $8 \%$ capital ratio, up from the $2 \%$ that currently holds under Basel II. To also increase their Tier 1 Capital reserves, the low-edge banks may also step down their dividend payout ratios in order to increase earnings retention for capital purposes 
On the other hand, with increased clarity as to the new capital requirements, the top-edge banks would likely be encouraged to raise their dividend payout ratios and share buybacks, since they would clearly have excess levels of capital. Furthermore, the top-edge banks would also have more capital to allocate to new business growth areas, mergers and acquisitions (Vetiva, 2010).

Moreover the Capital Conservation Buffer of $2.5 \%$ has been described as a welcome introduction, especially as it will basically be composed of common equity and retained earnings; and in addition to Core Tier 1 Capital of $4.5 \%$, will ensure that at least $67 \%$ of Banks' base capital structures is made up of fully loss absorbing capital, up from $25 \%$. However, it must be noted that in the build-up to the initial phasing-in period for this buffer by 2016, compliance efforts by Banks may stall asset growth and impact their profitability profiles negatively, as any extra capital reserved is an opportunity cost for a more significant asset growth (analysts estimate the opportunity cost could be as high as 1:15 for top American Banks). The impact of the Liquidity Coverage Ratio would also be mixed, as while on the one hand it will definitely raise the liquidity of Banks, it would on the other hand place downward pressure on profitability and Return on Equity, especially in a period where the use of leverage is being de-emphasized or discouraged. More sovereign paper implies more lower yielding securities in Banks' asset mixes relative to higher yielding risk assets; conversely, it is a 'backdoor' to helping the low-edge banks shore up their capital ratios, as these securities would have lower risk weightings in capital ratio computations. For quite a number of non-BIS countries where domestic debt markets are still nascent and lacking sufficient marketable sovereign/quasi-sovereign securities, implementing this ratio may prove challenging. Nevertheless, the implementation of this ratio is not expected till another 5 years (01 January 2015); thus, immediate impact will be near-nil, except in situations where the 'backdoor' proves favorable for some Banks.

In Nigerian context, are there any immediate implications from Basel III? Vetiva (2010) are of the view that any such implications are still way off, more so because Nigeria is yet to fully implement Basel II, with most progress having only been made with pillar 1 - minimum capital requirements and risk management. Notably, for most of the progress that has been made, it was not until the tenure of the current CBN Governor, Sanusi Lamido Sanusi, that Nigeria began enforcing risk management frameworks in Nigerian Banks and commenced risk-based supervision. However, a lot of what we have now are still merely frameworks which are yet to be fully tested under varying economic cycles. Furthermore, considering that Nigerian Banks are still well capitalized, with over $90 \%$ of their equity being Tier 1, Basel III has no material and immediate implications for Nigeria. This can be clearly seen with figures in Table 3 below:

Table 3.1 $\quad$ - $\quad$ Cleared Banks Capital Adequacy Ratios as at 2010

\begin{tabular}{|l|l|l|}
\hline S/N & Bank & Capital Ratio \\
\hline 1. & Fidelity & $40 \%$ \\
\hline 2. & FCMB & $40 \%$ \\
\hline 3. & Zenith & $28 \%$ \\
\hline 4. & Stanbic-IBTC & $35 \%$ \\
\hline 5. & Access & $32 \%$ \\
\hline 6. & Ecobank & $24 \%$ \\
\hline 7. & Guaranty Trust & $26 \%$ \\
\hline 8. & First Bank & $16 \%$ \\
\hline 9. & Diamond & $20 \%$ \\
\hline 10. & Skye & $17 \%$ \\
\hline 11. & UBA & $16 \%$ \\
\hline 12. & Sterling & $12 \%$ \\
\hline
\end{tabular}

Vetiva Research, 2010

As can be seen Nigerian banks have capital adequacy ratios well above the $8 \%$ prescribed by Basel II. But as observed earlier, Basel III recommendation will have no immediate consequence for Nigerian banks.

\section{Abolition of Universal Banking Concept}

The Guidelines for the Practice of Universal Banking in Nigeria issued by the CBN on 22 December 2000 (Universal Banking Guidelines), introduced a new specie of banks; outside the contemplation of the Banks and Other Financial Institutions Act, 2004 (BOFIA) that is, the Universal Bank. This Guideline gave impetus to the incursions by the banks into diverse non-banking businesses. However, the reforms in the Nigerian financial sector brought to the fore, concerns over the risks to which depositor's funds were exposed due to the activities of some of the banks.

To address the above concern and thereby ensure that depositors' funds are adequately ring-fenced, and that banks focus on core-banking business (which falls within CBN's regulatory radar), the CBN undertook a review of the Universal Banking Model. This review also involved 
a comparative analysis of structures (such as Holding Company structures) used in other financial markets to adequately segregate business, function and risks, where diverse financial services are undertaken through separate entities within a financial supermarket. In addition, comments were received from key industry stakeholders and this served as input towards the finalization of the exposure draft document which was circulated by the CBN in March 2010.

Sequel to the exposure draft, the CBN published the Circular on the Review of the Universal Banking Model dated 7 September, 2010 with reference number BSD/DIR/GEN/UBM/03/025. The circular outlined the intentions of the CBN to repeal the Universal Banking regime and enjoined the banks to submit their Compliance Plans to the CBN. Consequently, on 8 November, 2010, the CBN repealed the Universal Banking Guidelines via the Regulation on The Scope Of Banking Activities \& Ancillary Matters, No. 3, 2010 (the 2010 Regulation), which principally abolished the Universal Banking Model amongst others. Note, that whilst the 2010 Regulation is dated 4 November 2010, its Commencement Date is 15 November, 2010.

\section{Highlights of the 2010 Regulation}

The 2010 Regulation comprises of about 11 (eleven) sections and in the main, deals with the following broad issues:

Reverses the Universal Banking Guidelines - whilst the 2010 Regulation takes effect almost immediately, this does not invalidate any acts done pursuant to the Universal Banking Guidelines, between the Commencement Date and the Effective Date 14 May 2012.

Re-instates the narrow definition of banking as contemplated under BOFIA - Section 66 of BOFIA circumscribes the permitted activities for banks though the Governor of the CBN may, by Order published in the Gazette, designate certain other business as banking business.

Prohibits banks from establishing, maintaining or permitting to exist, any Related Enterprise Related Enterprise is defined in the 2010 Regulation to mean any (x) Associate, (y) Subsidiary or (z) Enterprise which a bank controls, possesses common directorship or equity interest in. However, banks may, with the permission of the CBN, maintain a foreign banking institution as a Related Enterprise.

Other exceptions include (x) permitted investments under Section 21(1) and 22(1)(c) of BOFIA; (b) approved companies jointly owned by two or more banks for certain developmental purposes; and (c) Custodians licensed as such under the Pension Reform Act, 2004.

Requires banks to dispose of all real estate interest acquired for purposes other than for use

business premises.

Prohibits banks from funding or otherwise investing in political activities or the like.

Banks are required to divest themselves of interests in Related Enterprises except as permitted by the 2010 Regulation - To ensure the integrity of this process, the divestiture should be on an arm's length basis and should take into consideration, the interests of stakeholders such as depositors and shareholders.

Requires banks currently operating under a Universal Banking License, to submit a Compliance PlanThis Compliance Plan should be approved by the board of the bank and submitted to the CBN within 90 days of the Commencement Date of the 2010 Regulation. The Plan is required to detail amongst others, the type of banking license such bank proposes to operate and how the bank intends to situate itself within the provisions of the 2010 Regulation. Where it considers the Compliance Plan satisfactory, the CBN shall grant the bank an approval-in-principle. This entitles the bank to commence restructuring of its operations, in line with the new regime. Failure to submit a Compliance Plan or obtain an approval-in-principle within the stipulated timeframe, would entitle the CBN to vary the license conditions of the bank, in order to bring it in conformity with the current licensing regime.

Requires banks to apply to the CBN not later than 60 days prior to the Effective Date, for a license to operate as one of the bank types permitted under BOFIA - These are limited to Commercial Banks, Merchant Banks and Specialized Banks (non-interest banks, microfinance banks, development banks and mortgage banks. Subject to relevant rules, regulations, and guidelines on licensing, authorization, operation and conduct of business that the CBN may issue periodically, the Commercial Banks referred to above may carry on banking business on a regional, national or international basis. For example, Wema Bank Plc, recently applied to $\mathrm{CBN}$ seeking a banking license, to operate as a regional bank with the regulatory capital requirement of N10 billion.

Application for a license - This may be made further to an approval-in-principle by the CBN, or pursuant to a variation of the existing Universal Banking License held by a bank as a result of its failure to obtain an approval-in-principle or submit a Compliance Plan within the stipulated timeline. A successful applicant shall submit its Universal Banking License in exchange for one of the permitted banking models. 
Where a bank fails to obtain a banking license by the Effective Date, such a bank shall cease to carry on banking business in Nigeria and consequently, shall deliver its Universal Banking License to the CBN.

Following the release of this final guideline on Commercial and Merchant Banking by September 2010, the CBN gave the much expected clarity which brings to an end, the 10-year age of Universal Banking in Nigeria. Similar to the underlying rationale behind the introduction of Basel III requirements on the global scene, the repeal of Universal Banking was premised on the model's observed weaknesses in ensuring safety of depositors' funds in the aftermath of the recent economic and financial crisis. With the setting aside of the one-model-fitsall structure, the CBN will now require Universal Banks (currently all Banks) to divest from all their nonBanking businesses and focus solely on Commercial/Merchant/Specialized Banking (the CBN's preference) or form a Holding Company structure in the event that the Bank desires to retain its non-Banking subsidiaries. The minimum standards on Commercial and Merchant Banking have already been published. But unlike Basel III which may not have any material impact on Nigerian Banks in the near to medium term, the abolishment of Universal Banking would have quite significant implications for investors, earnings, valuations, Banks themselves and the Nigerian economy at large. Before delving into these, it is appropriate review the operation of the erstwhile universal banking in Nigeria.

\section{Evolution of Universal Banking in Nigeria}

According to Uzor (2010) the introduction of universal banking in Nigeria in 2000 was the climax of a trend towards a submersion of institutional boundaries among banks which began in 1990s. The trend itself was triggered by high competition on the liability side of the balance that followed the CBN liquidity tightening measures in 1980s. The first major hit on banking liquidity happened in 1986 when import deposits awaiting foreign exchange releases were de-monetized. The second measures came in May 1989 when the Central Bank directed all public sector related deposits in commercial banks to be transferred to the apex bank. The several liquidity cuts set banks on the most aggressive battle that turn out to be a lethal combat. A critical element of survival strategy was the pressure from the banks to remove regulatory restrictions in competing for deposits. Between 1990 and 2000, banking regulation gradually responded to these demands. The first regulatory nod for the eventual crumbling of institutional barriers between commercial and merchant banking came in 1991 . Banks and other Financial Institutions Act (BOFIA) No. 251991 granted commercial banks permission to engage in equipment leasing business which was hitherto reserved for merchant banks. The decree permitted banks to own subsidiaries financial institutions which they held unofficially then. By then, diversification of operations of other arms of services industry was in full gear and the permission granted in the decree was in reality an endorsement of an unstoppable trend. Other regulatory responses soon follow reinforcing the trend towards the disappearance of institutional boundaries in the banking industry. This include the lowering of minimum deposit amount merchant banks were permitted to take from N50,000 to N10,000. The reduction at a period of high inflation and highly depreciated exchange rate meant virtually a permission to retail banking. In August 1996, the Central Bank of Nigeria exempted merchant banks from observing cash reserve requirement and mandatory allocation of credit to the small scale enterprises. This was in the effort to redress their competitive disadvantage. A major barrier however remained, which was the exclusion of merchant banks from providing payment services to customers by use of cheques. This constrained the ability of merchant banks to access interest free liabilities. This barrier became a growing source of discontent and agitation to create a level playing field continued. In June 1999, the Central Bank responded to this demand by offering merchant banks the option to convert into commercial banks. The regulatory move provided a big door of opportunity to merchant banks and applications for conversion flowed. By the end of 2000, not less than 10 merchant banks had converted to commercial banking. Conversion from merchant to commercial banking was an escape from operating restrictions in a highly competitive environment. Besides, the objectives for delimiting commercial and merchant banking such as avoiding conflicts of interests, excessive risk taking and possible abuses in credit and investment operations where no longer tenable in the environment of liberalization and deregulation of financial services market. By the end of 1990 decade, the eventual end of commercial and merchant banking distinctions has come. In 2000, the Central bank surveyed the operating environment for universal banking and gave approval to its introduction in principle. The guideline for universal banking was issued in December 2000 creating a level playing field for all banks for the first time to extend their frontier beyond traditional banking services. Under the guidelines, banks were permitted to engage in any or a combination of money markets, capital market activities and insurance services. However, after 10 years of operations of universal banking, it become obvious that there were inherent abuses which include conflicts of interests, excessive risk taking and insider abuses. The banking crisis that the country witnessed within the 10-year operation of universal banking was an eloquent testimony of the wisdom of separating commercial banking from investment banking. The commercial banks in Nigeria clearly over-stretched their level of competency and capacity in an attempt to 
become financial supermarkets. The economic recession which pulled down many global banks and exposed multiple weaknesses in regulation and banking structures further gave credence to the need to once more 'ringfence' core banking from non-banking influences. The universal banking was finally abolished in 2010.

\subsection{New Licensing Model}

According Datatrust (2010) the main target of the new licensing model is to withdraw the permission to banks to engage in non-traditional banking activities. A bank will only be licensed to operate core banking services specifically defined in its mandate. Since it cannot engage in other financial market activity, it will not be permitted to own a subsidiary. In fact, it will not need subsidiaries within the same geographical market. Expansion of business will be vertical only into new geographical markets and no longer horizontal into noncore banking business. This will ensure that a bank concentrate and specializes in the core banking business rather than trying to be a financial supermarket, where fraudulent directors often use subsidiaries to loot the banks. A bank will become either commercial or merchant. A merchant bank is required to have a minimum paid up share capital of N15bilion. A commercial bank may be one of three types - regional, national or international with minimum paid up requirement of N10billion, N25billion and N50billion respectively. There will be specialized banks under which Primary Mortgage Institutions, Discount Houses, Development Banks and Micro-Finance Banks are grouped. New comers to this group are the Non-interest banks, which may opt to be either regional or national.

According to Uzor (2010) an important innovation in the new model is the return from shareholders fund to paid-up share capital in defining minimum capitalization benchmarks for banks. The implication of this is that some banks will have to capitalize their reserves to comply with the requirement, while some others will need fresh equity injection to meet the regulatory requirements. To the banks with negative equity capital, the new capital requirement is a big mountain ahead. They will need to make massive injection of new funds to cross the regulatory hurdle. As at 2010 bank capitalization, 11 banks are in position to meet the requirement of N50billion paid up capital for international banks without raising new money. They include Zenith Bank, First Bank, Guaranty Trust Bank, United Bank for Africa, Access Bank, Fidelity Bank, First City Monument Bank, Diamond Bank, Skye Bank, Stanbic-IBTC and Ecobank Nigeria. They will however, need to capitalize a large of amount of outstanding reserves, which are more than adequate for that purpose. According to Uzor (2010) because regulatory policy shifted from paid up capital to shareholders funds during the consolidation exercise, paid up amount of banks are presently quite low relative to equity base. Now that policy has swing back to paid-up capital, only the 11 banks are in a position to comply without fresh capital injection. Capitalization of reserves appears to be a more viable option for them than raising new money in the present circumstances.

There is wisdom in ring-fencing banking, according to the Central Bank from non banking business as a strategy to secure depositors funds. A good part of the huge losses that hit banks revenues and capital stocks during the financial crisis came from the operation of the subsidiaries. In effect, the operations of banks subsidiaries that are mostly not within the regulation of the central bank do expose depositors' funds to greater risk of loss. International banks do own banking subsidiaries in other countries only, which will not engage in any other business than banking. Operating mandate of foreign subsidiaries is however not within the Central Bank authority. It seems that foreign subsidiaries of international banks will be the escape route for banks to do offshore what they will not be allowed to do at home. This is because it is likely to be easier and less costly for an oversea subsidiary to set up a new outfit in a country of resident than its holding company at home to incorporate a new company in the same country. Some holding companies may resort to registering a local subsidiary that will oversee all its international operations. All foreign based subsidiaries will then come under the umbrella of such an institution.

Below is an overview of the new banking structure.

New Banking Model

\begin{tabular}{|l|l|l|l|}
\hline Universal Banking & Commercial Banking & Monoline Banking & Specialized Banking \\
\hline Banking & $\bullet \quad$ International & Merchant Banking & Microfinance \\
Insurance & $\bullet \quad$ National & & Mortgage \\
Asset Management & $\bullet \quad$ Regional & & Non-Interest \\
Stock-broking & & & - Regional \\
Pension Custodian & & & - National \\
Mortgage & & & \\
Trusteeship & & & \\
Issuing House & & & \\
Microfinance & & & \\
Registrar & & & \\
& & & \\
\hline
\end{tabular}

Holding Company Model 


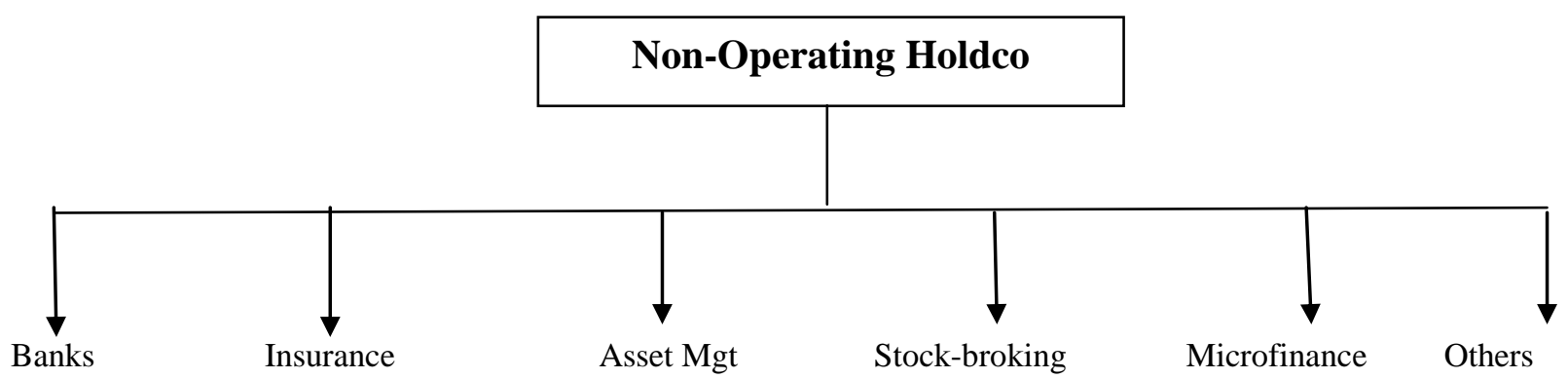

\section{The Holding Company Model}

According to the CBN exposure draft on the Holdco framework, the Holdco shall own a Bank (or Banks) and may also engage in other financial services activities closely related to Banking but only through non-Bank subsidiaries. It shall be an 'Other Financial Institution' (OFI) that owns at least (20\%) of the share capital of at least 2 Banks or one Bank and any other financial institution. The Holdco must own adequate voting stock in another Company to exercise control $(>50 \%)$ or significant influence $(>20 \%)$ of that Company's operations. The Holdco will be non-operating and will only be allowed to acquire, hold and administer permitted investments (defined under scope of operations/ permitted investments). A holding company model is an essential part of the new licensing structure as it provides a survival roof to house the numerous subsidiaries of banks already in existence. Without a holding company, all the existing subsidiaries of the banks will need to either be sold off or shut down. The repeal of the universal banking guideline requires banks to divest from all non-banking subsidiaries. The holding company is not expected to be restricted to hold equities in only banks and financial services organization. It will be owned by the shareholders that presently own the group of bank and its subsidiaries since it is a regulatory invention, the Central bank, is likely not to see the need to spell out restrictive operating framework for holding companies at this stage. Where a bank does not own its subsidiaries fully, only its proportionate share of the institution will be transferred to the holding company. Consequently, net profit made in a year will be split between equity holders of the parent company and non-controlling interest. The principal activity of a holding company will be to provide banking and other financial (or non financial services) depending on its regulatory authorization through its subsidiaries within the area specified in its operating license. A holding company will normally publish consolidated financial statement of its and that of the group of its subsidiaries. An income of a typical non-operating bank holding company will show dividend as its main revenue line, representing profit for the year. To the profit for the year, profit/loss from sales of investment and net valuation gain/losses are added or deducted to arrive at a comprehensive income for the period. The holding company can be expected to share some assets with its subsidiaries, such as buildings, human resources, information technology and other infrastructures. That means it will have an opportunity to earn an additional income and will also bear some costs, though it is considered non-operating. Such incomes and costs will however be relatively small.

According to Uzor (2010) the assets of the holding company constitute essentially investments in subsidiaries, which are represented by the sum of share capital and reserves on the liability side of the balance sheet. Consequently, in terms of the size of the balance sheet, a non-operating bank holding company will be significantly smaller than the group. This is because a principal asset and liabilities of the subsidiaries are not part of its financial position. The specific surgical operation that will happen is to detach ownership and control of banks subsidiaries from the bank itself. Ownership will be transferred to the holding company where a Group Chief Executive Officer is expected to reside. The Group Chief Executive Officer will have responsibility to oversee and report on the operations of the entire group. The CEO of the bank, like any of the other subsidiaries, will report to the Group Chief Executive Officer. Responsibility for realizing overall corporate objectives reside with the Group Chief Executive. To that responsibility attaches the authority for planning and implementation of a strategy needed to realize the group corporate targets. Who becomes the Chief Executive Officer of the holding company is not expected to be within the jurisdiction of the Central Bank. The change over to a holding company model is very likely to involve rationalization of existing subsidiaries of the banks. It is not likely that all the subsidiaries at present will continue to exist as separate entities. Some of the subsidiaries are likely to be collapsed to form about core areas of banks operations at the moment. These are banking, capital market and international market. The rest are insurance services and non-banks. Although there may be potential loss impact of the change in banking model on banks' earnings over the next few years through divestments, this would not be much considering the overall contribution of banks subsidiaries to their gross earnings and assets as shown in Table 4 below: 
Table 4.1: Subsidiary Contribution to Banks' Total Assets and Gross Earnings as at 2010

\begin{tabular}{|l|l|}
\hline Bank & $\begin{array}{l}\text { Average Subsidiary Contribution to Total Assets and Gross } \\
\text { Earnings }\end{array}$ \\
\hline Union Bank & $15.35 \%$ \\
\hline First Bank & $14.56 \%$ \\
\hline Intercontinental Bank & $12.91 \%$ \\
\hline Access Bank & $10.24 \%$ \\
\hline UBA & $10.08 \%$ \\
\hline Wema Bank & $9.87 \%$ \\
\hline Stanbic-IBTC & $7.10 \%$ \\
\hline Sterling Bank & $7.02 \%$ \\
\hline Zenith Bank & $6.78 \%$ \\
\hline Diamond Bank & $5.82 \%$ \\
\hline Afribank & $5.81 \%$ \\
\hline GT Bank & $5.52 \%$ \\
\hline Bank PHB & $4.47 \%$ \\
\hline FCMB & $3.72 \%$ \\
\hline Oceanic & $3.57 \%$ \\
\hline Skye Bank & $2.66 \%$ \\
\hline First Inland Bank & $2.63 \%$ \\
\hline Unity Bank & $1.79 \%$ \\
\hline Fidelity Bank & $1.37 \%$ \\
\hline SourC: Vetva Reant
\end{tabular}

Source: Vetiva Research, 2010

As can be seen from the above, only about 3 of the non-banking subsidiaries currently contribute over $10 \%$ of the Banks' Gross Earnings and Total Assets on the average. Even the contribution is only this high because subsidiary numbers as reported include off-shore banking operations. It must be noted that subsidiaries contribution is a combination of non-banking subsidiaries (domestic and international) and international banking subsidiaries.

It is pertinent to point out that where a holding company has a company registry as its subsidiary, the Central Bank is not going to allow the company to handle share registration for the bank. According to Uzor (2010) how it will enforce this rule at the group level, which will now come under the domain of other regulatory bodies, will depend on the level of cooperation among financial market regulators. Share registration flaws are believed to be so much that regulators are very likely unanimous in extending the restriction. Significant regulatory changes will need to happen to permit the change to the holding company structure.

At this point, we highlight the general features of the different banks under the new banking model.

Table 4.2 Characteristics of the New Banking Model

\begin{tabular}{|c|c|c|c|}
\hline $\mathbf{S} / \mathbf{N}$ & Bank Type & Capital & Key Characteristics \\
\hline \multirow[t]{3}{*}{1} & Commercial Banking & & $\begin{array}{l}\text { In addition to the generally acceptable business of } \\
\text { commercial } \\
\text { Banks, the new guidelines restricts Commercial Banks' } \\
\text { abilities to provide financial advisory services to only those } \\
\text { that are incidental to its normal business and do not require } \\
\text { regulatory filings with the Securities and Exchange } \\
\text { Commission. Furthermore, they are restricted from carrying } \\
\text { on any of the following businesses: insurance, loss adjusting, } \\
\text { reinsurance, asset management, issuing house, proprietary } \\
\text { trading (except as permitted) and any other business activity } \\
\text { that the CBN may from time to time restrict }\end{array}$ \\
\hline & (a) Regional Banking & N10 billion & $\begin{array}{l}\text { - Entitled to carry on Banking business within a } \\
\text { minimum of } 6 \text { and maximum of } 12 \text { contiguous } \\
\text { States lying within not more than } 2 \text { geopolitical } \\
\text { zones*, as well as within the Federal Capital } \\
\text { Territory. } \\
\text { Precluded from settlement bank activities }\end{array}$ \\
\hline & (b) National Banking & N25 billion & $\begin{array}{l}\text { - } \quad \text { Entitled to carry on Banking business within every } \\
\text { State } \\
\text { - } \quad \text {.Precluded from settlement bank activities }\end{array}$ \\
\hline
\end{tabular}




\begin{tabular}{|c|c|c|c|}
\hline & (c) International Banking & $\mathrm{N} 50$ billion & $\begin{array}{l}\text { - Entitled to carry on Banking business within all } \\
\text { States, as well as establish and maintain offshore } \\
\text { banking operations in jurisdictions of its choice, } \\
\text { subject to the approval of the CBN and } \\
\text { compliance with regulatory requirements of host } \\
\text { country } \\
\text { Precluded from settlement bank activities }\end{array}$ \\
\hline \multirow[t]{6}{*}{2} & Merchant Banking & 15 billion & $\begin{array}{l}\text { - Take deposits in an amount not below N100 } \\
\text { million per tranche } \\
\text { Provide finance and credit facilities to non-retail } \\
\text { customers } \\
\text { - } \text { Deal in forex and provide forex services } \\
\text { Act as Issuing House, subject to the provisions of } \\
\text { BOFIA } \\
\text { Provide underwriting services for equity issues, } \\
\text { subject to the provisions of BOFIA and prior } \\
\text { notification in writing to the CBN Provide treasury } \\
\text { management services, including the provision of } \\
\text { money market, fixed income and forex } \\
\text { management services on behalf of clients } \\
\text { Provide financial, consultancy and advisory } \\
\text { services relating to corporate and investment } \\
\text { matters, for a fee } \\
\text { Provide asset management services, securities } \\
\text { dealing and Brokerage } \\
\text { Proprietary trading; fixed income trading; } \\
\text { custodial services; debt factoring; issue, discount } \\
\text { and rediscount negotiable instruments. }\end{array}$ \\
\hline & Specialized Banking & & \multirow{3}{*}{$\begin{array}{l}\text { The draft framework for the regulation and supervision of } \\
\text { Non-Interest Banks is being finalized based on feedback } \\
\text { received from industry operators and key stakeholders. In } \\
\text { addition, the framework for Primary Mortgage Institutions is } \\
\text { being reviewed and finalized in terms of operations and } \\
\text { funding for the Mortgage Sector. Pending the issuance of } \\
\text { revised guidelines by the CBN, PMIs, Microfinance Banks } \\
\text { and Development Banks shall continue to } \\
\text { perform their specialized roles within the framework of } \\
\text { existing guidelines }\end{array}$} \\
\hline & (a) Microfinance bank & & \\
\hline & (b) Development Banks & & \\
\hline & (c) Mortgage Bank & N5 billion & \\
\hline & \begin{tabular}{ll} 
(d) & \multicolumn{1}{l}{ Non-Interest } \\
- & National \\
- & Regional \\
\end{tabular} & $\begin{array}{l}\text { N10 billion } \\
\text { N5 billion }\end{array}$ & \\
\hline
\end{tabular}

\section{Implication of the Abolition of Universal Banking and the New Banking Model in} Nigeria

Unlike Basel III which we observed earlier may not have any material impact on Nigerian banking in the near to medium term, the abolishment of universal banking model and the new banking model will have far reaching implication for the banks, the regulatory authorities especially the Central Bank and the economy in Nigeria. In a seminal work, Uzor (2010) highlight some of these implications namely, skewed playing field for banking competition, the return of ethnic banking and ethnic jingoism, the scramble for all banks to be classified as international banks, the enormous regulatory cost, increased instability in the banking system as a result of constant changes in policy and the apparent disconnect in objectives of the banking sector and the real sector.

\subsection{Uneven Playing Field for Competition}

According to Uzor (2010) banking, by its nature, is a business that thrives on reputation. Every bank strives to build around its personality image that creates confidence and pride of association among the banking public. When a potential depositor decides to open an account with a particular bank it is because he believes that bank is not in a way inferior to any other bank accessible to him. Competition in banking service has always been and will continue to be to portray an institution as superior in as many areas of operation as possible. Once a competitive edge is created by a bank for itself or for it through regulatory action, others who fail to match that advantage will be sure to lose business. During the period of financial distress in the banking industry in 1990s and to some extent even today, the appointment of a bank for revenue collection for a government or government agencies is regarded an indication that the bank is financially healthy. Soon most banks secured such revenue collecting contracts with various government institutions and freely brandish the 
appointment letters to potential depositors. Following the risk asset audit in the banks in 2009 and the classification of 8 banks as unhealthy, competition has tilted against problem banks to the advantage rated healthy. The new model that categorizes banks according to capital strength will ultimately create uneven playing field for competition.

\subsection{Implication on Return Regional Banks}

As regulatory action and policies affect competitiveness, so do the ability or inability of banks to render financial services will ultimately affect a bank's competitiveness. Hence a regional bank based in West will not attract people and institutions that do businesses in the East and North. If it is an existing bank, its clientele base will most likely split as people seek to open accounts with nationalized bank to be able to do what the regional banks will no longer be able to do for them. In that way, a regional bank will be shortening its operating horizon. According to the new banking model regional banks are permitted to operate in a minimum of six and maximum of 12 contiguous states of the federation, which must lie within two geopolitical zones. A major concern in that arrangement is that ownership is likely to reflect the chosen area of operation, which will reintroduce ethnic dimension in the banking business. According to Uzor (2010) in an era of high mobility of people and capital, it seems that the concept of regional banking needs a rethink. Such a bank does not appear to have been modeled towards customer orientation and will appear to be significantly disadvantaged in competition. If national banks can do all that regional banks can do and more, regional banks will gradually dim down to no more than microfinance banks and with time will be driven out from business completely. In a banking system where safety is yet to be attained, the notion will be if you are regional, you are not strong. As merchant banks pressed to be commercial banks in the 1990s, it can be expected that regional banks will be soon after begin to clamor to become national banks even for survival. It seems that it is better for the system that they are not created in the first place. There is however, just narrow door open for regional banks to establish a competitive edge and thrive in the country. This requires that they detract from general banking services and build their services around regional economy. A regional bank must of essence become an agricultural bank to develop survival route and a successful one at that. Perhaps, the Central Bank expect that with such banks, Nigeria could return to the era of groundnut pyramid in the North, the booming cocoa business in the West and the golden palm produce in the East. This will be wonderful but such banks will need to wear a complexion other than that of a commercial bank to be able to accomplish that goal. They will need longer term liabilities to provide development finance needed to build the plantations. If the central bank does not a have a clear answer as to how regional banks will be funded to get them deeply rooted in regional economies, such banks cannot survive in a competitive hostile environment waiting to stifle them at birth. To that must be added, concern about the hostile operating environment that are not conducive for small scale businesses to thrive in the country. According to Uzor (2010) how to sustain regional banks without growing regional economies will perhaps be a new lesson in business strategy. High mortality rate for small scale enterprises was the key factor that frustrated government owned development banks. Strong growth in regional economies is a key requirement for regional banks to have a competitive edge. Microfinance banks appear to have better prospect than regional banks. The significantly higher rates structure of microfinance banks gives them a competitive edge. Microfinance banks receive large funds in deposits because of comparatively higher interest rates they pay. They also charge as much as 50\% per annum for funds they disburse. Regional banks will appear to have neither the operating advantage of national banks nor the operating freedom of microfinance banks. With time, they will migrate either upwards to be national banks or downwards to the microfinance banking class.

\subsection{The Scramble For Who Becomes a National Bank?}

The prospects for national bank will be defined by the category of existing banks that will eventually belong to this group. According to Uzor (2010) there are four categories of competitive list of banks. These include industry leaders, made up of the largest banks that passed the central bank financial stress test and emerging banks, which are medium-sized and healthy banks. The rest are restructured banks which constitute the big and the small banks that were hardest hit during the financial crisis and the last are focused operators which are subsidiaries of foreign banks. Most of the industry leading members and emerging banks are already largely international banks by virtue of number of banking subsidiaries they have built offshore. Also, they have equity funds well above the paid up capital benchmark of N50billion specified under the new licensing structure. It can therefore, be taken for granted that they will apply for international banking license using their relatively large reserves to meet the paid up capital requirement. All that may be involved will be just accounting entries. It can be expected therefore, that regional banks will emerge from the host of the restructuring banks most of which presently wear a central bank label of unhealthy. That is exactly where their problem begins. Apparently, they will become national banks not be choice but because they have no other option. They lack the ability internally to become international banks suggesting that most of them that already have offshore subsidiaries would have to wound up such operations. If national banks eventually emerge in this 
way, the market will not forget that they have competitive impairment. Consequently, the market place use of term national banks will most likely refer to weakness. Such banks can be expected to continually fall below the red line of many organization list of approved banks for business relationship. Again since international banks can execute international transactions faster and perhaps at a lower cost, there can hardly be a justification for prime customers choosing a national bank. National banks cannot compete for funds business with international banks and win. The competitive disadvantage will likely return the system to the pressure to end its institutional distinctions once again and create level playing field just as it happened in the 1990s. The implication of the foregoing is that national banks are likely to be "banks in transition" This means no bank will like to start and stay as national bank and this applies also to regional banks that may have migrated into the group. While it may be the only option to get license as a regional bank, the target ultimately will be to become an international bank. As soon as each bank in this category puts its house in order, it will apply for international license even if all it does is to open obscure office in the West Coast backyard. A bank will need to wear the label of 'international' even for it to get business in national market. Looking ahead, remarked Uzor (2010), "I see empty seats in both regional and national banking category in a matter of two to years from licensing" The central bank policy will initially disturb the competitive equilibrium of banking industry and with time, the operators would converge once again in one equal class. Most banks will strive to become international banks and are likely to attend to that stature in a matter of a few years from system shake up.

\subsection{Niche Banks to Maintain the Edge}

According to Uzor (2010) niche operators are likely to remain focused on their prospective markets irrespective of whatever name they choose to call themselves? It would have been more appropriate for them to become specialized banks by virtue of their limited market focus. If they choose to answer national banks, their operations are likely to be national in nature; neither does retail banking fit into the strategy of these (mostly) foreign banks subsidiaries. These banks understand the market they serve and can be expected to stick to their niche no matter the new licensing tag they are made to wear. It is in respect of these classes of banks that the new licensing model will test its credibility. The new licensing structure will follow the criterion of how much a bank weigh on a capital scale. This suggest that foreign banks subsidiaries operating in Nigeria can apply and be licensed as national or international banks once they met the qualifying capital requirements. The possibility of foreign banks subsidiaries that operate here virtually as unit banks being licensed as national or international banks, need a total reconsideration. Licensing banks on the basis of capital base against different market coverage will be misleading. There is a presumption that banks that must meet higher capital requirements also carry higher operating risk. This will be interesting to the Nigerian Deposit Insurance Corporation for the purpose of calculating deposit insurance premium.

\subsection{Implication of Licensing Banks along Ethnic/Religious Lines}

According to Uzor (2010) the patchy peace and unity that have held Nigeria together for 50 years derive from official emphasis of its secularity and a deliberate play down of ethnic and religious differences. Apparently, if the Central Bank license banks that somewhat reflect regional and religious ownership interest, it may be with good intentions of promoting economic activities. In practical terms, however, that move will be subject to wide interpretations and misinterpretations. If we go down the path of history of banking development in Nigeria, it will become obvious how licensing one bank along regional or religious dimension easily spur competition in that direction. In the days of regional governments, each region competed to set up a regional bank. Western region registered Cooperative Bank of Western Nigeria in 1953 under the West Cooperative Societies Ordinance. The Eastern Nigerian government gave the Cooperative Union of Eastern Nigeria a grant of 10 pounds to set up the Cooperative Bank of Eastern Nigeria in 1954. The idea of Kaduna Cooperative Bank was first muted in 1960 but was eventually registered in 1972 as a North Central Cooperative Bank Limited. After the civil war, during which the regional system of government gave way for state structure, competition to built banks shifted to state governments. Every new state created along the line build a bank of its own. History is a proof that banks build for reasons other than pure commercial consideration will not be around for long. Of the 18 commercial banks in operations in 1977, 11 of them were owned either by state government or regions. Of those 11, only Wema bank is still in business today. If the Central bank licenses one regional bank, it will stand ready to license such bank for each identifiable region. The least it can expect will be 6 to cover geopolitical zone of the nation. Since the beginning of modern banking business in Nigeria, it has been impossible to separate politics from banking until the consolidation policy accomplishes that feat in 2005 . If banking business is to return to ethnic ownership and a religious dimension is added to it still, we must fast and pray hard that there will be no ethnic or religious violent again. If not, we will only be adding banks to the list of houses, churches and mosques that are usual targets for destruction during violence. Banks that wear religious colour will become the bank for children of God and other banks for unbelievers (sinners), if we let the 
marriage between religion and banking happen, it may not be possible for the Central Bank to ever put them asunder.

\subsection{Implication on Cost of Regulatory Compliance}

As rightly observed by Uzor (2010) every banking reform has a cost, some of which are quantifiable in money and others reflect in terms of time efficiency uses and customer inconvenience. A reform is tantamount to breaking down the existing structure and building up again a different one. The change process therefore, involves a slow down and in some cases, even complete stoppage of the system activities. Operators will have to return to the strategy room to recreate plans that will fit into the new operating environment. Consultants will be extensively involved in the process of knocking down the existing structures and re-building according to the regulatory mandates. Such consulting jobs on an entirely new organization model are likely to be hired from outside the country. Their fees will be expectedly be counted in foreign currency in a depreciating local currency environment. There will be need for the retooling in terms of both human and material resources. Part of the existing resources is bound to become obsolete as a result of structural change. Job losses cannot be ruled out in the process of rationalizing the existing subsidiaries of the banks. The extent of the structural overhaul that will take place and cost of its implementation will depend on how far or close a bank is from its operative target. International banks are very likely to have minimum structural change. Their main task will be to restructure existing subsidiaries. For banks that are already international in nature that will fold back into national or regional banks, the cost of such adjustment will be quite high. They will need to either sale or shut branches or subsidiaries presently outside their new operating jurisdiction. If a national bank shrinks into regional operations and later seek to re-enter the national market, the cost of exiting and re-entry will be enormous in terms of money, lost opportunities and strategic positioning in the market place. The cost and inconvenience to the banking public will also weigh high where a bank ceases to operate in the area. Will the bank choose to repay depositors their funds rather than give away hard won accounts to competitors on a platter of gold? Assume the central bank directs that such branches be sold to other banks, can it also guarantee that the selling bank and the potential buyer will agree on price? If they don't, what happens? If they do, the process of integrating the acquired branch will involve cost implication and inconveniences of service disruption, particularly where technology platforms are different. The direct implication of a once national bank folding into regional entity is lost of market share. There is just one condition under which that development is not going to be a problem in longer term. That is where there is a compensatory gain of market share in regional markets. Regulatory incentives will be required to provide competitive advantage that can make that happen. Extreme caution is needed however, in fashioning policies that may tamper with operating freedom and liberalization in the market place. Regulatory policies must of necessity avoid creating captive market that restricts competition in the banking industry. If other banks are significantly hindered in competing within the domain of regional banks, their holding companies will move to plant regional or specialized banking subsidiaries to counter these advantages. It is not anticipated that a holding company will be restricted from owning more than one type of bank in its group. If regulatory policies tilt more to the side of excessive limitation to the holding company in systems that claim to be market-based, they are not likely to be sustainable. In a matter of time, it can be expected that holding companies will become the most powerful cartel to the economy. Only then will the full implication of central bank policy become clear: removing power from banks it can control and giving it to holding companies that it cannot control. A major issue of concern is indeed, how soon the banking sector will attend stability, which is important for it to devote more time serving the market than adjusting from one reform to another. It is apparent that the proposed changes will delay the attainment of that much needed stability.

\subsection{Timing of the Policy change}

There is no ideal time to institute a policy change in terms of physical calendar. A policy change must first happen before the good or bad effect will be felt. The question therefore is - what is the nature of the policy input and the results anticipated? Because measures in the banking sector are transmitted to the rest of the economy, regulators need to be fairly certain as to what changes the intended policy will make in the economy. Policy changes will be justified at any point in time if it can be shown that anticipated benefits far exceed the cost of the system disturbance. Because banks are the medium to effect desirable changes in the real sector, it is important for the central bank to show how its proposed policy changes will stimulate economic growth and development across sectors and industries. The problem of banking reforms has been their focus on changes within the banking sector rather than the real economy that should determine what changes are desirable in the first place. The need for changes in the banking sector which is a service industry ought to be driven by discovery of new opportunities in the real sector. Any changes in the banking sector that are not warranted by new developments in the number of sectors in the real economy are not going to be much beneficial. A banking reform is expected to fit into the overall economic development strategy of the nation. 
Changes that are taking place in the economic structure should determine changes to be made (if any) in the banking policy. A major fallout of the banking consolidation policy is that it set out to build the banking sector and not the economy per se. The main target was to build banks as big as the big banks in other countries. The reform policy seems to withdraw large resources from the rest of the economy to accomplish that purpose. In the end, there were no ready channels for the huge resources placed in the hands of the banks to get into productive activities. This led to the excessive concentration of the banks in financial markets. It is important that the central bank does not allow this costly mistake to happen the second time. It needs to be pretty certain how the desirable changes needed in the rest of the economy warrant the changes it has proposed in the banking sector in clearly measurable terms. Banks are servants to the economy and cannot reasonably set out on a mission to transform the servant without showing how that move fit into the strategy of accomplishing the master's objective.

\section{Conclusion}

From the foregoing, it is apparent that the abolition of universal banking and the introduction of the new banking model have multiple implications both for the banking system, the regulatory authorities and the economy in general. How far and how well the new banking model is able to achieve its intended goals depends on how well the regulatory authorities are able the resolve the various challenges we have highlighted in this paper. More importantly the regulatory authority should learn from the banking history of Nigeria and not embark on another rigmarole and policy inconsistency that has characterized our financial industry for the past three decades. It is therefore recommended that the Central Bank of Nigeria should not rely on the new banking model as a panacea to the perennial banking system instability in Nigeria but should focus attention in ensuring macroeconomic and monetary stability to enable not only banking business but other businesses to thrive in the country.

\section{References}

[1]. Bank of England (2010) “The Bank's new indexed long-term repo operations" Quarterly Bulletin, Q2, 90-91.

[2]. Banks And Other Financial Institutions Act, 1991 As Amended.

[3]. BCBS (2008) "Principles for Sound for Liquidity Risk Management and Supervision" Bank for International Settlement.

[4]. BCBS (2010) Basel III - International Framework for Liquidity Risk Measurement, Standards and Monitoring, Bank for International Settlement.

[5]. Bindseil, U. and F. Papadia, (2009) Risk management and market impact of central bank credit operations, in U. Bindseil, F. Gonzalez and E. Tabakis (eds): Risk management for central banks and other public investors," Cambridge University Press.

[6]. Bindseil, U., (2011) Theory of monetary policy implementation, Chapter 1 of F. Papadia and P. Mercier, The concrete euro, Oxford University Press, pp. 5-114.

[7]. Borio, C. (2008) "The Financial Turmoil Of 2007" A Preliminary Assessment AndSome Policy Considerations.

[8]. Brunnermeier, M., A. Crocket, C. Goodhart, A.D. Persaud, H. Shin (2009) “The Fundamental Principles Of Financial Regulation", Geneva Reports On The World Economy, 11.

[9]. Brunnermeier, M. (2009) "Deciphering The Liquidity And Credit Crunch 2007-2008", Journal Of Economic Perspectives, Vol. 23, No. 1.

[10]. Chailloux, A. S. Gray and R. McCaughrin (2008) Central Bank Collateral Frameworks: Principles And Policies, IMF Working Paper WP/08/222

[11]. Central Bank of Nigeria (2010) Circular on the Review of Universal Banking Model

[12]. Central Bank of Nigeria (2010) Draft Framework for the Regulation and Supervision of Non-Interest Banking in Nigeria

[13]. Committee on the Global Financial Stability (2008) Central Bank Operations in Response to theFinancial Turmoil, Bank for International Settlement

[14]. Olaniwun, A. (2010) "Reversal of Universal Banking in Nigeria", African Journal of Banking and Investments, Vol. 11, No. 4, pp $2-4$.

[15]. Ulrich, B. and J. Lamoot (2011) “The Basel III Framework For Liquidity Standards And Monetary Policy Implementation” SFB 649 Discussion Paper, European Central Bank.

[16]. Uzor, M. (2010) "New Banking Model in Nigeria: Challenges and Opportunities”, Zenith Economic Quarterly, Vol. 5, No. 4, pp. 29-33

[17]. Vetiva Capital Management (2010) Banking Update: The Next Chapter, Journal of Asset Valuation and Management, 3(5), pp 812 